\title{
Marketing Vision for Higher Education Institutions From the Perspective of Quality and Perceived Value in the Post-COVID-19 Time
}

\author{
Jose Luis Matarranz \\ Complutense University of Madrid \\ Jesús García-Madariaga \\ Complutense University of Madrid
}

For these two last years, COVID19 pandemic has been a challenge for Higher Education (HE) institutions. The challenge has been to convert many face-to-face process into online or virtual learning process. Although many institutions have been focused on online methodology for years, this stage has provided them an opportunity to consolidate competitive advantages developed previously. An US institution of HE focused on online graduate programs is used as a case study. This research turns out the different perceptions of its former students and their intention to return to the institution at the institution. To address this problem, we have used the PLS method.

Keywords: higher education, perceived quality, perceived value, PLS, post-COVID19

\section{INTRODUCTION}

Circulation restrictions motivated by the COVID19 pandemic, which has significantly influenced the Higher Education (HE) sector, has brought with it the need to tackle the challenge of the online education. Hence, there has been an explosion and on offer of line programs and there is a need to identify online programs and methodologies that really have an impact on the learning and transformation of students in the virtual context. The COVID-19 circumstances have accelerated the supply and demand of training through virtual platforms. It is in the hands of HE institutions to mobilize relevant and valuable innovation to turn this current challenge into progress for humanity.

Leadership and training consultancies are already proposing new models applicable to post-COVID19 scenario when, probably, companies will bet in an executive training focused on the internet environment. This paper wants to help marketers educate and guide future consumers of the infinite world offer to distinguish the value proposition of the different online programs.

\section{Companies}

Human resources have a golden opportunity to break paradigms and generate a change in the culture of virtual training and development. They must be strategic in the adoption of impact methodologies, otherwise the risk of deepening the already existing paradigms that restrain virtually will increase. 


\section{People}

Those interested in studying online, must learn to choose not only by price. It is key to distinguish if they are buying knowledge, learning or growth.

\section{Universities and Consultants}

The challenge is not to transfer traditional methodology to the virtual world through new platforms. The challenge is not to transfer traditional methodology to the virtual world through new platforms. The challenge is to innovate in deep methodological processes that transcend information (knowledge), generate learning and growth (transformation) and this is an opportunity to progress.

In this line, Tete Foster Leadership consulting has been working for some business school from Spain and USA, developing the following figure.

\section{FIGURE 1 \\ THE MATRIX OF ONLINE 2.0 EDUCATION}

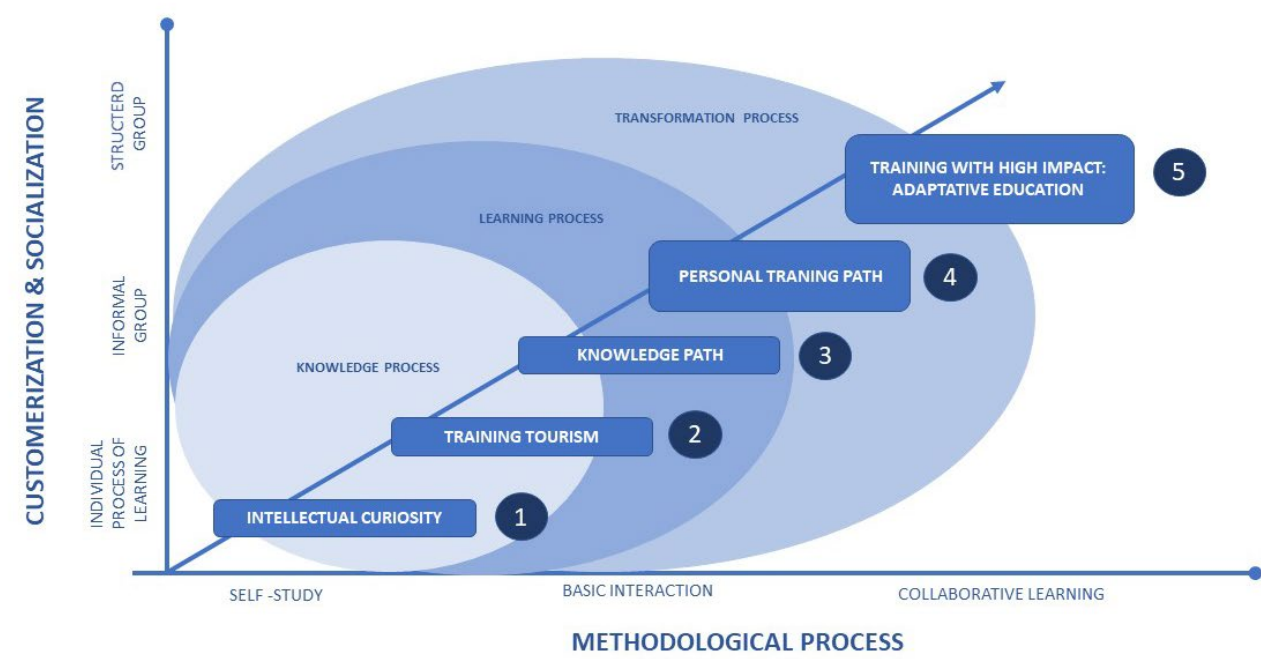

Source: Tele Foster Leadership (2020)

This study tries to adopt these insights to the models described in the academic literature about marketing for HE institutions. From our perspective, variables such as the service quality and perceived value are related to the educational objectives described by the consultant firms.

Our study tries to demonstrate that transformer model in education requires a high level of perceived quality and value. We plan a survey at a HE institution in USA. This institution is focused on online executive programs for more than fifteen years and this circumstance was interpreted as a real opportunity. The name of the institution is Westfield Business School in Florida.

\section{THEORETICAL FRAMEWORK}

A new framework should encourage HE institutions to strive for excellence in their daily performances to direct their students toward further learning opportunities.

Nowadays there is a constant need to learn and acquire new skills. Everybody is living in the digital age and the technological advances which have taken place in the last twenty years at a faster rate than at any other moment in human history. This is a clear challenge for all educational institutions in the world which have also an opportunity and a responsibility for the professional development of managers and executives. 
For example, for this century, executive education is undergoing a radical transformation even before the pandemic crisis of COVID19. Today's programs are far more innovative, student-centered, and relevant to the immediate needs of business more than ever. Today, executive education has the potential to play an even greater role as a main tool to facilitate strategic changes in the companies (Conger \& Xin, 2000).

The shift of executive education accelerated in 1990s. The transformation was preceded by the new challenges brought about by global competition, rapid technical advances, merges and acquisitions, a growing importance in the reducing cost, and the popularity of the alliances between corporations (Conger \& Benjamin, 1999; Conger \& Xin, 2000). All this meant a change of perspective toward leadership competencies for the future (Vicere, 1998) and particularly, Master in Business Administration (MBA) degree was a widely accepted qualification in business management (Baruch \& Peiperl, 2000).

Topics such as globalization, employee diversity, alliances, organizational learning, and e-commerce have grown in importance since the last years of 1990s. The economic crisis of 2007, with Lehman Brothers crack, provided a new change in the paradigm of the executive and managerial education, and now, other new crisis appears in the scenario even more global and with a greater impact on people's lives.

The world claims the needing of a new generation of managers and executives, who can manage suitable and profitable business impacting positively in the triple bottom line (economic, social, and environmental). This change of paradigm and the continued development of the digital environment mean that human beings (executives or not, managers or not) must recycle their knowledge permanently. The training of executives and professionals is no longer a reward, but an obligation to fulfill its mission.

On the other hand, HE has undergone a great transformation in support of the knowledge economy, at least in the last past 20 years. Technological changes have fueled the globalization of HE, likely accelerating the rate of transforming HE into a commodity that can attract international customers through private spending and on a global scale (Maringe \& Gibbs, 2009).

\section{Student-as-Customer and the Perception of Quality}

Authors have debated largely about the consideration of students as customers or not, and the debate is polarized. Advocates regard it as self-evident that students are customers and should be treated as such, while reviewers regard it as self-evident that the incursion of the "customer" concept into HE degrades educational standards and prejudices educator/student relationships (Clayson \& Haley, 2005; Eagle \& Brennan, 2007; Melewar \& Akel, 2005).

But the problem should not be seen this way in this case. Students should be considered clients from the point of view of the attraction to the institution; the application to an institution and the final election to study on it. For this sequence, the marketization should be used as a tool of management, as a useful tool to maximize efforts focused on the recruiting the best students for each institution and university, emerging the relations between student and teacher later.

An examination of literature, that describes the efforts of the quality in the HE, found that most authors agreed that the difficulty of defining higher education's customer is the greater barrier to stablish the quality improvement goals in the HE (Quinn, Lemay, Larsen, \& Johnson, 2009).

For years, quality has often been related only to manufacturing or only to design, assuming that quality was the lack of defects and that quality design was related, above all, to compliance with procedures and requirements. However, this point of view associated to the operative and productive worlds, also stepwise has gone relating to the commercial world. The quality in the commercial environment has much to do with the expectations, perceptions, and satisfactions of the final client.

Also, quality could be related especially to the expectation that the client has and with the value proposition that he receives, being of "inferior quality" when the expectation is greater than the proposal and of "superior quality" when the proposal of value received it is greater than the expectative that he had.

Owlia and Aspinwall (1997) examined in their work the differences between HE and industry and how these differences affect cross-application of quality techniques. While industry quality techniques often suggest studying the market (the real needs of customers) and focusing on quality to meet these needs, the motivation of the academic world is independent of the market requires. Ewell (1993) pointed out that the skeptical nature of the academy makes "fashionable" industry quality techniques suspect. 
However, over the last few years this idea has been reversing. There are already many educational institutions that are certified and use the criteria established in the procedures and quality models as guides for their management. The education market assumes these criteria normally and understands that quality certifications are criteria that are positively valued by future students at the time of choosing an institution.

The terms 'service quality' and 'quality in education' are difficult to define. Perceptions of service quality often differs based on the requirements of the service's individual customer. In the educational setting, one customer might consider a certain class, curriculum, or university a high-quality educational experience while another might find the same experience mediocre (Quinn, Lemay, Larsen, \& Johnson, 2009).

The literature suggests that HE began focusing on quality improvement efforts during the 1990s, owing to increased competition for students and operational funds. Competition for funds, resources, and good students has intensified (Hwarng \& Teo, 2001) and institutions are facing a fast-changing world with everchanging needs and ever-increasing demands for capable and competent graduates. Consequently, an institution must be operated effectively and efficiently and be able to deliver quality programs (Hwarng \& Teo, 2001).

Owlia and Aspinwall (1997) stated that HE was being driven towards industry-style competition because of changing economic conditions. During the 1990s students were becoming 'more savvy' and discriminating, state's funding formulas were changing, and non-governmental funding sources became more selective - leading to the increased focus on quality (Canic \& McCarthy, 2000).

The different studies carried out in recent years have measured quality in HE institutions through topics such as internationalization, marketing and support, access and accessibility of services (De Jager \& Gbadamosi, 2010), or on dependability, effectiveness, capability, competencies, unusual situation management and semester-syllabus (Sultan \& Wong, 2010a).

On the other hand, perceived quality has continued to be measured through tangibility (facilities, computer/science lab library, equipment) (Calvo-Porral et al., 2013; Chandra et al., 2018; Hwang \& Choi, 2019), but considireng that aspects such as response capacity, empathy, trustworthiness, guarantee (CalvoPorral et al., 2013; Chandra et al., 2018; Hwang \& Choi, 2019; Pedro et al., 2018) are also present in the perception of quality. The use of two general dimensions (tangible and intangible) to measure students 'perceptions about service quality in HE has also been supported by Nadiri et. al (2009) who found that these dimensions would be a good predictor of student satisfaction (Duque, 2014; Nadiri, et al., 2009), and the perceived value, too.

Indeed, this has meant that customers (students) have gone further, becoming the active element in the judgement of products (courses and programs) and services in terms of quality and therefore their value, their possible success or their possible failure.

\section{Perceived Value in High Education}

Perceived value is linked with the customer's overall assessment of a service or a product. The concept of perceived valued is based on equity theory (Can \& Erdil, 2018; Christodoulides \& De Chernatony, 2009; Keller, 1993). On the other hand, perceived value factor is the consumer's general evaluation of the value of a product, which is based on consumer's perceptions (Zeithaml, 1988). More specifically, the concept means that there is a difference between received benefits and its costs (e.g., financial and psychological) (Dlâcic et al., 2014).

From the customer's perspective, a product or brand that has superior attributes than other alternative is selected, because it is expected that product performance had better satisfy their needs. Costumers tend to prefer products with high-perceived value. Perspectives of consumers perceived value can be analyzed through functional value, emotional value, social value, and brand loyalty (Yeh et al., 2016).

In the case of the Higher Education, the value based on student's perceptions would be the via to measure this value beyond the brand equity of institutions. There is no doubt that the brand of universities with a large reputation influences more student's perceptions, although it is very possible that other students also have a very good perception of their institutions, because not all students can enroll in the best universities all over the world whose brand equity is highly recognized. 
Program's quality, staff and faculty, services, and hosting and facilities would be the indicators to determinate the perceived value and this assessment will indicate the perceived value for students.

Some researchers to measure the customer perceived value can use a uni-dimensional variable, using just one statement (e.g., value for money) for evaluating overall value (Sweeney et al., 1997), or as a multidimensional variable (Sweeny \& Soutar, 2001). Sweeny and Soutar (2001) described the development of a 19-item measure, PERVAL, that is used to assess customers' perceptions of the value: emotional, social, quality /performance and price/value for money. This scale was also tested in a post-purchase and prepurchase situation and, and the results found to be reliable and valid in both cases.

When the concept of perceived value is defined in an HE context, the trade-off approach is emphasized (Dlâcic et al., 2014). In this aspect, the trade-off of the education is linked with teaching performance and, so, the teaching assessment is a of the main focal point in the improving of the educational organization. The existing practices such as student feedback through the questionnaires and on-site peer evaluation, are mostly limited to in-class teaching performances (Chen et al., 2014), and to measure the perceived value could be able to use other methods and scales without limits.

For instance, the value perceived by a student is the overall evaluation made of the utility of the service. This service is based upon the perception of that which is received and that, given which could be achieved through all previously mentioned tools (Ledden, Kalafatis, \& Samouel, 2007).

Dlâcic et al., (2014) concluded that the concept of customer-perceived is multifaceted, and it considers the functional aspects of HE experiences, student emotions, and comparison with alternatives. In addition, more studies with multidimensional measures of value have continued to emerge in recent years, (Beckett et al., 2020), with the following dimensions as attainment value, utility value and intrinsic value (Pham et al., 2019). Other works, too, using multidimensional mesurements, have evaluated the perceived value through the teaching staff, the infraestructures, the administration staff and the support services (DoñaToledo et al., 2017) or also, aspects such as the functional value, relational value-fellows, intrinsic value, epistemic value, relational value-staff, conditional value, extrinsic value or emotional value in a same study for a $\mathrm{HE}$ instituion, using a questionnaire with 40 items (Dziewanoswska, 2017).

\section{RESEARCH METHODOLOGY}

This research has included a data collection through a survey of graduates of a US higher education institution, using as a tool of electronic questionnaire sent by $e$-mail to study their behavior intentions.

The method chosen to analyze the data and test the model has been the technique of Partial Least Squares (PLS, "Partial Least Squares"). The main objective of this technique is the prediction of latent variables, from the modification of ordinary least squares, and the analysis in variance as principal analysis components.

The questionnaire consists of two parts. The first part consists of two blocks, and each block contains each of the independent latent variables that are integrated into the model: one concerns quality service perception (20 questions), and the other on perceived value (6 questions). To answer these questions, a Likert scale from 1 to 7 is used, considering that answer 1 represents total disagreement or that the probability that it occurs is $0 \%$ and answer 7 represents a total agreements or that the probability that it happens is from a $100 \%$.

Over the last 20 years, authors have used the SERVQUAL scale to measure service quality in a wide selection of industries with varying success. Normally perceived service quality is measured with a modified SERVQUAL scale (Parasuraman, Zeithaml, \& Berry, 1988) and most of the studies conducted on service quality in last 25 years are based on the SERVQUAL model (Yildiz, 2014). SERVQUAL is a multiple-item scale for measuring perceived quality service, designed to be applicable across a broad spectrum of service.

An examination of the content of the final items making up each of SERVQUAL's five dimensions suggested the following labels and concise definitions for the dimensions:

Tangibles: $\quad$ Physical facilities, equipment, and appearance of personnel.

Reliability: $\quad$ Ability to perform to promised service dependably and accurately. 
Responsiveness: Willingness to help customer and provide prompt service.

Assurance: $\quad$ Knowledge and courtesy of employees and their ability to inspire trust and confidence.

Empathy: $\quad$ Caring, individualized attention the firm provides its customers.

Modifications have been applied to the items since the analysis to these five dimensions of SERVQUAL scale to approximate to the HEI variables and perceived service quality is measured with a modified SERVQUAL scale. Dlâcic et al. (2014) proposed a modified scale using 24 items to measure the perceived service quality. We use a modified questionnaire for our research that allows us to measure the dichotomy and interrelation between customer perception and expectation in response to current contexts ( $\mathrm{Yeo} \& \mathrm{Li}$, 2014).

\section{TABLE 1 COMPONENTS FOR PERCEIVED QUALITY MEASUREMENT}

\begin{tabular}{|l|}
\hline Up-to-date equipment. \\
\hline Visually appealing physical facilities. \\
\hline Appearance of physical facilities. \\
\hline Sympathetic and reassuring faculty management. \\
\hline Dependable faculty. \\
\hline Receiving prompt service from teaching staff. \\
\hline Receiving prompt service from non-teaching staff. \\
\hline Willingness to help students (non-teaching staff). \\
\hline Trustful teaching staff. \\
\hline Trustful non-teaching staff. \\
\hline Polite teaching staff. \\
\hline Polite non-teaching staff. \\
\hline Adequate job support for teaching staff. \\
\hline Adequate job support for non-teaching staff. \\
\hline Faculty provides personal attention. \\
\hline Teaching staff provides personal attention. \\
\hline Non-teaching staff provides personal attention. \\
\hline Teaching staff knows students' needs. \\
\hline Be interest at heart \\
\hline
\end{tabular}

This part of questionnaire has been designed to measure the performance mainly of the facilities, faculty and non-teaching staff, expecting to obtain results that allow us to measure the correct functioning of different parts of a HE institution, which will have been decisive in the relationship with the students during their stays at the universities and colleges. In the present case, teaching and non-teaching staff are the main indicators for this research due to online relations stablished with students, however, throughout the program, students can visit offices, buildings and other facilities related to the institution.

Likewise, for years the authors have applied questionnaires to assess the perception of value that students have about their institutions. This variable is focused on capturing the different components that has for customers: emotional, social, quality, price and performance and value for money. For this, scales as PERVAL have emerged to measure the construct.

Our questions suggest that perceived value can be regarded as a "consumer's overall assessment of the utility of a product (or service) based on perceptions of what is received and what is given" and this assessment is a comparison of a product or service's "get" and "give" (Zeithaml, 1988, p. 14). The commonest interpretation of this trade-off has been to consider the relation between price and quality (Cravens , Holland, Lamb, \& Moncrief III, 1988; Monroe, 1990; Sweeny \& Soutar, 2001) although other 
authors have also suggested that seeing value as a trade-off between only quality and price is too simplistic (Bolton \& Drew, 1991).

Therefore, it is necessary understanding view of value about providing "superior value to the buyer in terms of product quality, special features, or after-sale service" (Porter, 1990). And it is the scope of the questionnaire that we propose in the research beyond the price and the trade-off of the paid money.

From this point of view and the model that collects this idea: "get" value and "give" value (Ledden, Kalafatis, \& Samouel, 2007), we plan a questionnaire linked with functional value (FV) mainly. The questions suggested, we allow to know the students' opinions about the benefits achieved during the stays in the institutions.

A first component of perceived value would be related to functional value for the student, when the stay at a university supposes improvements professional for him. We understand this benefits as the possible advancements that alumni can get after that their chosen course of study will gain them new employments or career advancements (LeBlanc \& Nguyen , 1999; Martensen et al., 1999; Stafford, 1994):

- My relationship to school is greatly beneficial to me.

- It is more valuable to me study at school than with other schools.

- I consider it very advantageous to be a student at school.

On the other hand, we try to evaluate the "give" components of the perceived value, but not only related to the monetary effort. There are other important efforts that must be considered: personal efforts, selfsacrifices, etc., which require giving up both family life and leisure, for example. Therefore, our questions address both the sacrifices made in monetary terms (course fees, accommodation costs in international experience weeks, textbooks, etc.) and non-pecuniary efforts taken during the stay at a HE institution away (time, energy, self-sacrifices, etc.) (Brown \& Mazzoral, 2009; Ledden, Kalafatis, \& Samouel, 2007; Webb \& Jagun, 1997).

- I consider that the fee (cost of registration) corresponds to the value that the course made in this Institution.

- I consider that the dedication, the effort, and the time dedicated agree with what has contributed me in knowledge acquired in the course.

Last question of this part of the questionnaire tries to collect information about a general perception of the perceived value that the student has, after her or his stay, of the HE institution: "my association with XYZ has been of value to me", how to interpret one-dimensional measured through a question like (Webb \& Jagun , 1997).

- Overall received from the Institution personally has an extremely high value for me.

This part of questionnaire has been designed to measure the overall perception of value that alumni have, considering the accomplishments reached and too, the efforts undertaken. Inasmuch as alumni consider that they have gained their professionals goals (better salary, better labor position on the organization or professional advances) and the necessary efforts have been rewarded (family time, leisure, etc.) we can obtain a complete measurement of perceived value.

The survey has been conducted by via email with the sending of designed questionnaire from the server of the institution that has participated in this study. This method allows the sending of emails in batches to the registered addresses. Recipients have only had to type their answers through the Google Forms electronic tool, which automatically calculates the answers.

Westfield Business School from United States is a HE institution that it was stablished in 2012 with license of CIE (Commission of Independent Education, in Florida) to operate executive programs: MBA, executive MBA and executive Financial Master (www.westfield.education). Its alumni community has more the 2.000 members graduated. Westfield Business School is in Doral, Dade County close Miami (Fl) and a total of 117 responds were obtained. 


\section{RESULTS}

The research model was tested using PLS, which has several strengths that make it appropriate for this study. The model proposed represent the relationships between perceived quality, perceived value an repurchase intention, where the value appears as a mediator value between the other two. The aim is to demonstrate that value acts favorably regarding the repurchase intention once that quality has been evaluated.

Prior the evaluation of this hypothesis we need to validate this measurement model. To component the model, we have used reflective indicators, each measured on a seven-point Likert scale and SmartPLS has been the used software for this work.

Before results, this procedure requires two previous steps: firstly, it is necessary to evaluate the reflective measurement model and, secondly it is necessary the structural model assessment.

When reflective items are used in a PLS model, the previous calculation requires evaluating the internal consistency reliability, the convergent validity and the discriminant validity (Hair, Sarstedt, \& Hult, 2017) and, also in PLS, item reliability is assessed by examining the loading and all loading must to exceed the recommended threshold of 0.7 (Carmines \& Zeller, 1979).

According to the results obtained in a first calculation, two indicators must be eliminated in the model to meet the requirement that it must be higher than the threshold of 0.7: PQ1(Up-to-date equipment) and PQ2 (Visually appealing physical facilities).

\section{FIGURE 2 \\ GRAPHIC MODEL FOR SMARTPLS CALCULATION}

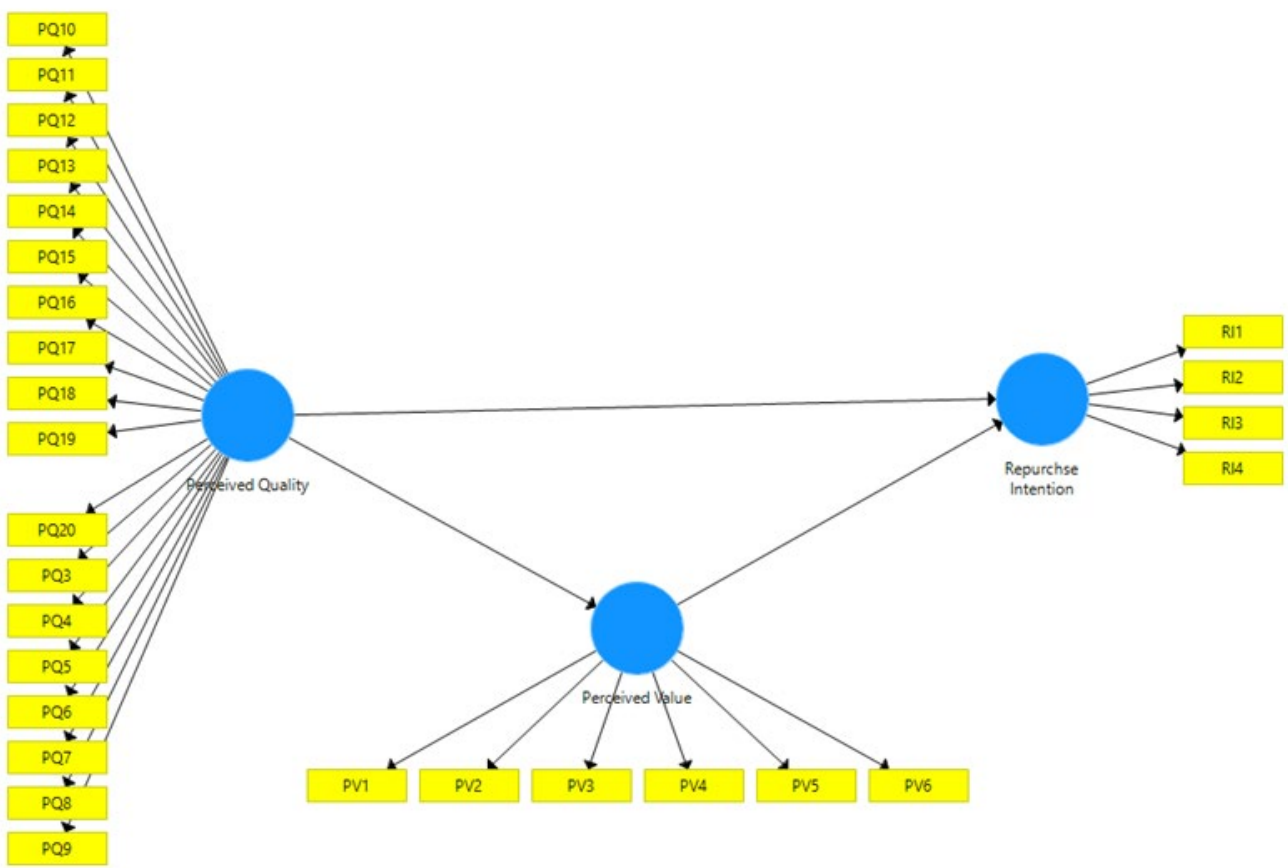

Source: authors 
TABLE 2

EXTERNAL LOADING FACTORS FOR REFLECTIVE INDICATORS

\begin{tabular}{|c|c|c|c|c|c|c|c|c|c|}
\hline \multicolumn{6}{|c|}{ PERCEIVED QUALITY } & \multicolumn{2}{|c|}{$\begin{array}{c}\text { PERCEIVED } \\
\text { VALUE }\end{array}$} & \multicolumn{2}{|c|}{$\begin{array}{c}\text { REPURCHASE } \\
\text { INTENTION }\end{array}$} \\
\hline PQ1 & -- & PQ7 & 0.847 & PQ14 & 0.906 & PV1 & 0.916 & RI1 & 0.829 \\
\hline PQ2 & -- & PQ8 & 0.730 & PQ15 & 0.850 & PV2 & 0.887 & RI2 & 0.909 \\
\hline PQ3 & 0.862 & PQ9 & 0.878 & PQ16 & 0.796 & PV3 & 0.927 & RI3 & 0.816 \\
\hline PQ4 & 0.812 & PQ10 & 0.784 & PQ17 & 0.878 & PV4 & 0.876 & RI4 & 0.886 \\
\hline PQ5 & 0.845 & PQ11 & 0.850 & PQ18 & 0.781 & PV5 & 0.914 & & \\
\hline PO6 & 0.883 & PO12 & 0.857 & PO19 & 0.702 & PV6 & 0.935 & & \\
\hline & & PQ13 & 0.907 & PQ20 & 0.784 & & & & \\
\hline
\end{tabular}

Modified the model with the suppression of these indicators, traditionally, "Cronbach's alpha" is used to measure internal consistency reliability in social science research and, also the composite reliability of the construct is used to assess this reliability. The interpretation of both indices is similar, since Cronbach's alpha coefficients that are above 0.7 (Nunnally, 1978; Peterson, 1994) and composite reliability of the construct that are above 0.6 (Henseler, 2010) are considered acceptable values.

Also, to check convergent validity, each latent variable's Average Variance Extracted (AVE) is evaluated. All AVE values must be greater than the acceptable threshold of 0.5 , so convergent validity is confirmed (Marin-Garcia \& Alfalla-Luque, 2019). Thus, Alpha of Cronbach, composite reliability and AVE are used to assess the convergent validity of the measurement model.

TABLE 3

INTERNAL CONSISTENCY AND CONVERGENT VALIDITY

\begin{tabular}{|l|c|c|c|}
\hline Latent Variables & $\begin{array}{c}\text { Alpha of Cronbach } \\
\text { (AC) }\end{array}$ & $\begin{array}{c}\text { Composite Reliability } \\
\text { (CR) }\end{array}$ & $\begin{array}{c}\text { Average of Variance } \\
\text { Extracted (AVE) }\end{array}$ \\
\hline Perceived Quality & 0.975 & 0.977 & 0.705 \\
\hline Perceived Value & 0.958 & 0.966 & 0.827 \\
\hline $\begin{array}{l}\text { Repurchase } \\
\text { Intention }\end{array}$ & 0.884 & 0.920 & 0.741 \\
\hline
\end{tabular}

To assess discriminant validity, Fornell and Lacker (1981) suggested the use of average variance extracted (AVE), which should be greater than the variances shared among constructs. Discriminant validity is an assessment of the extent to which a construct differs from other constructs. The comparison can be made in a correlation matrix, including the correlations among different constructs in the off-diagonal elements of the matrix, and the square roots of the AVE for each of the constructs along the diagonal. For adequate discriminant validity, the diagonal elements should be greater than the off-diagonal elements in the corresponding rows and columns.

TABLE 4

FORNELL-LACKER CRITERION

\begin{tabular}{|l|c|c|c|}
\hline & Perceived Quality & Perceived Value & Repurchase Intention \\
\hline Perceived Quality & $\mathbf{0 . 8 4 0}$ & & \\
\hline Perceived Value & 0.823 & $\mathbf{0 . 9 1 0}$ & \\
\hline Repurchase Intention & 0.493 & 0.623 & $\mathbf{0 . 8 6 1}$ \\
\hline
\end{tabular}


Analysis of the internal consistency of the scales it allows specifying the degree of rigor with which a set of indicators are measuring the same latent variable.

The test of the structural equation model includes an estimation of the path coefficients and $\mathrm{R}^{2}$ value. The path coefficients represent the standardized regression weights. These data require measures of how well the proposed model fits the observed data. The path coefficients indicate the strengths of the relation among dependent and independent variables, and $\mathrm{R}^{2}$ value represent the among of variance explained and is a measure of the predictive power of a model for dependent latent variables: 0,67 is a substantial value, 0.33 is a moderate value and 0.19 is weak value for the predictive power Chin (1998).

Also, Chin (1998) recommended that standardized path coefficients be greater than 0.2 but negative path coefficients can emerge in some models when there is a competitive partial mediation, for example.

For this study, also the Stone-Geisser redundancy index have used to measure the model predictability (Geisser, 1975; Stone, 1974). The values of this index must be positive to guarantee the reproducibility of the original value of the model.

TABLE 5

$R^{2}$ AND $Q^{2}$ STATISTICS

\begin{tabular}{|l|c|c|}
\hline & $\mathbf{R}^{\mathbf{2}}$ & $\mathbf{Q}^{\mathbf{2}}$ \\
\hline Perceived Value & 0.678 & 0.556 \\
\hline Repurchase Intention & 0.389 & 0.277 \\
\hline
\end{tabular}

Lastly, bootstrapping is a resampling procedure since it treats the sample as the population and from it extract with replacement many samples of size $n$. Each sample is replaced from the original data set, usually until the number of cases is the same as the original sample set Chin (1998). Bootstrap offers the $t$-Student values, being significant those indicators greater than 1.96. In general, $t$-Student " $\mathrm{t}$ " values are used to determinate which relationship (hypotheses) are statistically significant. Next table shows the result about the bootstrapping procedure of the three relationships established for this model for perceive quality and value, with repurchase intention in the context of HE.

TABLE 6

STANDARDIZED PATH COEFFICIENTS, T-STUDENT VALUE, AND P-VALUE

\begin{tabular}{|l|c|c|c|}
\hline & $\begin{array}{c}\text { Path } \\
\text { Coefficient }\end{array}$ & $\begin{array}{c}\boldsymbol{t} \text {-Student } \\
\text { Value }\end{array}$ & $\boldsymbol{p}$-value \\
\hline Perceived Quality $\rightarrow$ Perceive Value & 0.823 & 16.662 & 0.000 \\
\hline Perceived Quality $\rightarrow$ Repurchase Intention & -0.062 & 0.499 & 0.618 \\
\hline Perceived Value $\rightarrow$ Repurchase Intention & 0.674 & 5.325 & 0.000 \\
\hline
\end{tabular}

TABLE 7

TOTAL EFFECTS, T-STUDENT VALUE, AND $p$-VALUE

\begin{tabular}{|l|c|c|c|}
\hline & $\begin{array}{c}\text { Path } \\
\text { Coefficient }\end{array}$ & $\begin{array}{c}\boldsymbol{t} \text {-Student } \\
\text { Value }\end{array}$ & $\boldsymbol{p}$-value \\
\hline Perceived Quality $\rightarrow$ Perceive Value & 0.823 & 16.662 & 0.000 \\
\hline Perceived Quality $\rightarrow$ Repurchase Intention & 0.493 & 0.499 & 0.618 \\
\hline Perceived Value $\rightarrow$ Repurchase Intention & 0.674 & 5.325 & 0.000 \\
\hline
\end{tabular}




\section{FIGURE 3 \\ PLS RESULTS}

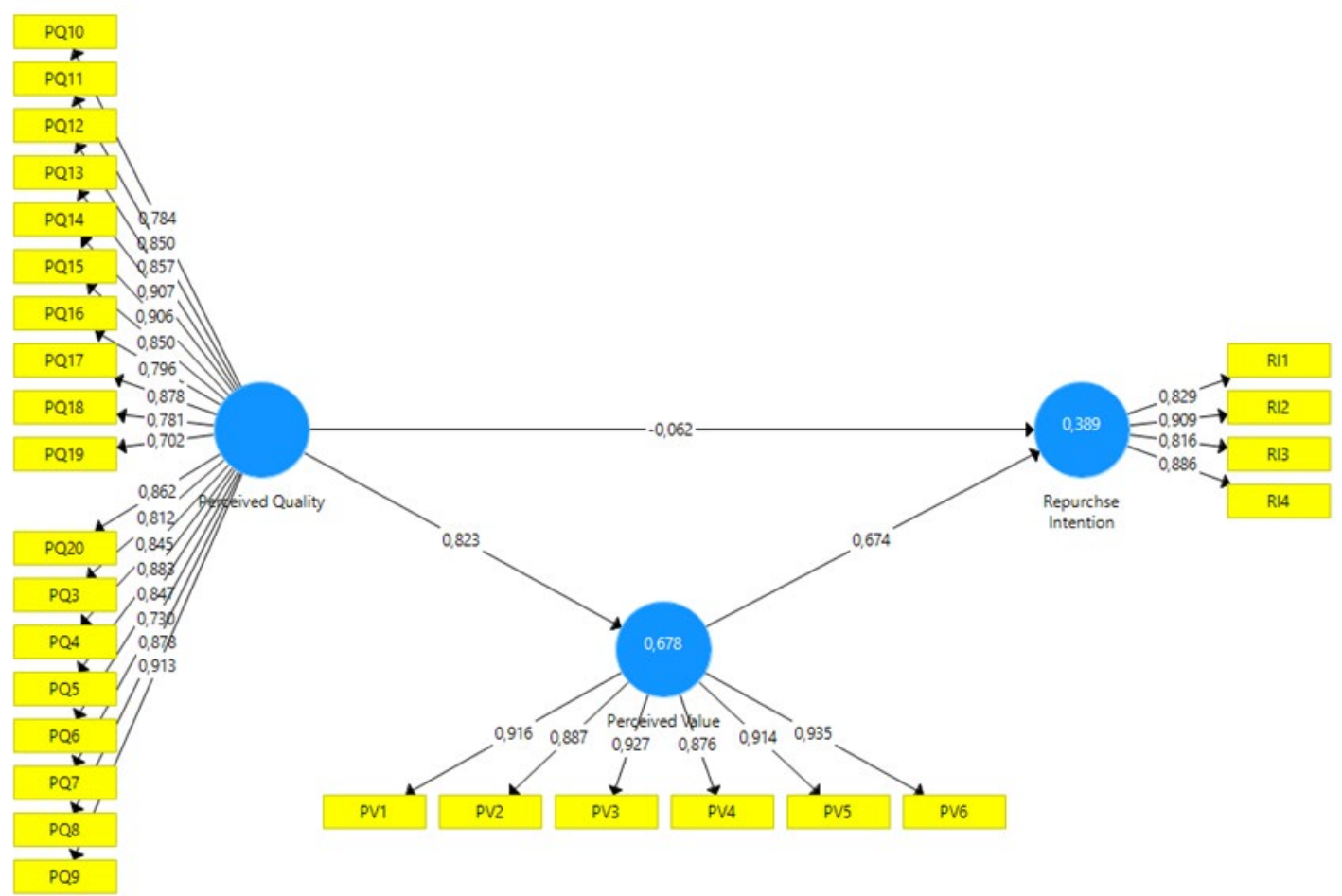

\section{FINDINGS AND DISCUSSION}

The analysis carried out allows us to study the relationships between perceptions and behaviors related to customer loyalty, which on this time is the student who has completed postgraduate studies at a HE institution. Dlačic et al. (2014) proposed a model to study the relations between the same variables with EFA - factors analysis and our results have been obtained with a PLS analysis.

First, our results point out that this measurement model is adequate, having been validated using the parameters thar PLS suggests. Only two reflective indicators have been suppressed because they were less than 0,7 (Carmines \& Zeller, 1979), thus we consider that the rest of perceived quality indicators, eighteen items, are enough to measure the perception of quality that student has. We even consider a new version of this research using less indicators of perceived quality to eliminate the possible collinearity between items that build the latent variable.

All tests carried out within this study point out that measurement model is valid: internal consistency, convergent validity and discriminant validity checks have been positive. The table 3 is built according to Fornell-Lacker criteria to validate the discriminant validity and too, it contains the correlation between the variables. As seen in the table, the highest correlation will be between perceived quality and perceived value.

The other important part of this study has to do with the validation of the structural model. Chin (1998) stablished that $\mathrm{R}^{2}$ greater than 0,6 joined to the standardized path coefficients are the calculations to validate the structural model. According to results, variance of perceived quality explains more than $60 \%$ of the perceived value variance and more than $30 \%$ of the repurchase intention variance. It means that $\mathrm{R}^{2}$ is substantial for perceived value and is moderate for repurchase intention. In terms of standardized path coefficients, the results obtained show that relationship between perceived quality and perceived value is significant $(t$-Student $=17.374 ; \mathrm{p}<0.001)$ and also, the relation between perceived value and repurchase 
intention is significant $(t$-Student $=5.273 ; \mathrm{p}<0.001)$. However, the $t$-Student doesn't reaches 1.96 value to validate a positive relation between the quality and repurchase.

Furthermore, the analysis data allowed us to significantly validate a positive relationship between the three latent variables ( $\mathrm{t}$-Student $=4.654 ; \mathrm{p}<0.001)$. Therefore, it can be stated that the relationship between the three variables will be positive with a high probability. The repurchase intention should be a result of the good practices of systems and performance that service quality represents and the perceived value that a former student has after of her/his stay at a HE institution.

The size of sample could perhaps be a limitation to definitely affirm that the perceived value is better antecedent than the quality to predict future behaviors of the customers such as repurchases. Therefore, we hope to continue with these lines of research in the future: we need to delve into the behavior of the alumni in this post COVID19 era, where the online education can reach a new goals for many people. Many paradigms about online education are broken during the months of confinement and this is the moment for that many HE institutions to learn from this new environment.

\section{CONCLUSIONS}

This research seeks an explication of the behaviors of former students after completing a bachelor's or master's degree at a HE institution. We want to know what the probability of returning to the same institution after a first experience at a university. From the point of view of the management of a higher education institution, this term is important because it can help optimize resources for recruiting for example. HE institutions, like all firms and companies must be profitable and sustainable over time. A marketing objective will always be to retain the customer and repurchase is a sign of this. Finally, the repurchase has turned into the final goal of this work since we obtained results that indicate that the perceived value is a better antecedent than the service quality to repurchase intention. The PLS analysis with reflective items allowed us to validate a measurement model and structural model for the repurchase intention based on quality and value. If perceived value were the better predictor for managing the repurchase in a HE institution by its alumni, it would be an effective tool to recruit students in future by the reducing attraction costs.

In a scenario such as the post-COVID19 pandemic, it seems logical to think that online education will continue to grow, since most users of university platforms will have been satisfied with the services received, demonstrating that it is possible to study without having a presence, especially important for executive and professional teaching. However, a more competition and offer will also have emerged and so, students as any customers, will be able to choose from a large number of proposals. This means that HE institutions are facing a very valuable opportunity but also facing a considerable challenge.

For the case studied, a business school focused on the way of teaching online, it will be essential to take care of all aspects related to perceived quality, knowing that quality is not a guarantee of final success. However, all efforts that are focused on increasing the perceived value will serve to manage a marketing strategy of loyalty with a high probability of success.

In summary, quality is not enough to attract or to maintain loyal behaviors and, probably only the proposals based on the value for the student will be the successful actions to get the return to their already known institutions, and as quality has a considerable impact on perceived value of student, it will be a requirement that HE institutions ought to have a very high levels of quality. For an institution like the one studied in this research and whose objective is to achieve a transformative learning model with structured groups that can have interactions between them, the performance of platforms or systems will not be enough. To the extent that the institution can delve into the social, emotional, and epistemological dimensions of the value provided to the student, the objectives linked to both will be more likely to be attainable. 


\section{REFERENCES}

Baruch, Y., \& Peiperl, M. (2000). The impact of an MBA on graduate careers. Human Resources Management Journal, 10(2), 69-90.

Beckett, R.D., Isaacs, A.N., Montagano, K.J., Sheehan, A.H., Ramsey, D.C., \& Sprunger, T. (2020). Perceived Value of Teaching and Learning Curriculum Programs Among Pharmacy Practice Department Chairs. American Journal of Pharmaceutical Education, 84(12), 1595-1602.

Bolton, R., \& Drew, J. (1991). A multistage model of customers' assessments of service quality and value. Journal of Consumer Research, 17(4), 375-384.

Brown, R., \& Mazzoral, T.W. (2009). The importance of institutional image to student satisfaction and loyalty within higher education. Higher Education, 58(1), 81-95.

Calvo-Porral, C., Lévy-Mangin, J-P., \& Novo-Corti, I. (2013). Perceived quality in higher education: An empirical study. Marketing Intelligence \& Planning .

Can, Y., \& Erdil, O. (2018). Determining Antecedent of Re-Purchase Intention: The Role of Perceived Value and Consumer's Interest Factor. International Business Research, 11(4), 11-31.

Canic, M., \& McCarthy, P. (2000). Service quality and higher education do mix. Quality Progress, 33(9), 41-46.

Carmines, E., \& Zeller, R. (1979). Reliability and validity assessment (Vol.17 ed.). Sage publications.

Chandra, T., Ng, M., Chandra, S., \& Priyono. (2018). The effect of service quality on student satisfaction and student loyalty: An empirical study. Journal of Social Studies Education Research, 9(3), 109131.

Chen, C-Y., Chen, P-C., \& Chen, P-Y. (2014). Teaching quality in higher education: An introductory review on a process-oriented teaching-quality model. Total Quality Management \& Business Excellence, 25(1-2), 36-56.

Chin, W.W. (1998). The partial least squares approach to structural equation modeling. Modern Methods for Business Research, 295(2), 295-336.

Christodoulides, G., \& De Chernatony, L. (2010). Consumer-based brand equity conceptualization and measurement: A literature review. International Journal of Research in Marketing, 52(1), 43-66.

Clayson, D., \& Haley, D. (2005). Marketing models in education: Students as customers, products or partners. Marketing Educational Review, 15(1), 1-10.

Conger, J., \& Benjamin, B. (1999). Building leaders: How successful companies develop the next generation. San Francisco: Josey-Bass.

Conger, J., \& Xin, K. (2000). Executive Education en the 21st. Centuary. Journal of Management Education, 21(1), 73-101.

Cravens, D.W., Holland, C.W., Lamb, C.W., \& Moncrief, W.C., III. (1988). Marketing's role in product and service quality. Industrial Marketing Management, 17(4), 285-304.

De Jager, J., \& Gbadamosi, G. (2010). Specific remedy for specific problem: Measuring service quality in South African higher education. Higher Education, 60(3), 251-267.

Dziewanoswska, K. (2017). Value types in higher education-students' perspective. Journal Types in Higher Education-Students' Perspective, 39(3), 235-246.

Dlacic, J., Arslanagic, M., Kadic-Maglajlic, S., Markovic, S., \& Raspor, S. (2014). Exploring perceived service quality, perceived value, and repurchase intention in higher education using structural equation modelling. Total Quality Management, 25(2), 141-157.

Doña-Toledo, L., Luque-Martínez, T., \& Del Barrio-García, S. (2017). Antecedents and consequences of university perceived value, according to graduates: The moderating role of Higher Education involvement. International Review on Public and Nonprofit Marketing, 14(4), 535-565.

Duque, L.C. (2014). A framework for analysing higher education performance: Students' satisfaction, perceived learning outcomes, and dropout intentions. Total Quality Management, 25(1), 1-21.

Eagle, L., \& Brennan, R. (2007). Are students customers? TQM and marketing perspectives. Quality Assurance in Education, 15(1), 44-60.

28 Journal of Higher Education Theory and Practice Vol. 21(8) 2021 
Ewell, P.T. (1993). Total quality \& academic practice: The idea we've been waiting for? Change: The Magazine of Higher Learning, 3(49-55), 25.

Fornell, C., \& Larcker, D.F. (1981). Evaluating structural equation models with unobservable variables and measurement error. Journal of Marketing Research, 18(1), 39-50.

Geisser, S. (1975). The predictive sample reuse method wirh applications. Journal of the American Statistical Association, 70(350), 320-328.

Hair, J.J., Sarstedt, M., \& Hult, G.T. (2017). A primer on partial least squares structural equation modeling (PLS-SEM) (2nd edition). SAGE.

Henseler, J. (2010). On the convergence of the partial least squares path modeling algorithm. Computational Statistics, 25(1), 107-120.

Hwang, B., \& Teo, C. (2001). Translating customers' voices into operations requirements-A QFD application in higher education. International Journal of Quality \& Reliability Management, $18(2), 195-226$.

Hwang, Y-S., \& Choi, Y.K. (2019). Higher education service quality and student satisfaction, institutional image, and behavioral intention. Social Behavior and Personality: An International Journal, $47(2), 1-12$.

LeBlanc, G., \& Nguyen, N. (1999). Listening to the customer's voice: examining perceived service value among business college students. International Journal of Education, 13(4), 187-198.

Ledden, L., Kalafatis, S., \& Samouel, P. (2007). The relationship between personal values and perceived value of education. Journal of Business Research, 60(9), 965-974.

Marin-Garcia, J., \& Alfalla-Luque, R. (2019). Protocol: How to deal with Partial Least Squares (PLS) research in Operations Management. A guide for sending papers to academic journals. WPOMWorking Papers on Operations Management, 10(1), 29-69.

Maringe, F., \& Gibbs, F. (2009). Marketing higher education: Theory and practice (First ed.). New York: McGraw-Hill Education .

Martensen, A., Gronholt, L., Eskildsen, J., \& Kristensen, K. (1999). Measuring student oriented quality in higher education: Application of the ECSI methodology. Verona: Proceedings from the TQM for Higher Education conference "Higher Education institutions and the issue of total quality".

Melewar, T., \& Akel, S. (2005). The role of corporate identity in the higher education sector: A case study. Corporate Communications: And International Journal, 10(1), 41-57.

Monroe, K. (1990). Pricing: Making profitable decisions. McGraw-Hill Companies.

Nadiri, H., Kandampully, J., \& Hussain, K. (2009). Students' perceptions of service quality in higher education. Total Quality Management, 26(3), 422-442.

Nunnally, J.C. (1978). Psychometric Theory (2nd ed.). New York: MaGraw-Hill.

Owlia, M.S., \& Aspinwall, E.M. (1997). TQM in higher education-a review. International Journal of Qualiy \& Reliability Management, 14(5), 527-543.

Parasuraman, A., Zeithaml, V., \& Berry, L. (1988). SERVQUAL: A Multiple-Item Scale for Measuring Consumer Perceptions of Service Quality. Journal of Retailing, 64(1), 12-40.

Pham, H-H., Lai, S.L., \& Vuong, Q-H. (2019). The Role of Subjective Task Value in Forming Satisfaction and Loyalty Among Vietnamese International Students: A Structural Equation Model. The Asia-Pacific Education Researcher, 28(5), 399-409.

Pedro, I.M., Pereira, L.N., \& Carrasqueira, H.B. (2017). Determinants for the commitment relationship maintenance between the alumni and the alma mater. Journal of Marketing for Higher Education, pp. 1-25.

Porter, M. (1990). The competitive advantage of nations. Harvard Business Review, 2(73-93), 68.

Quinn, A., Lemay, G., Larsen, P., \& Johnson, D. (2009). Service quality in higher education. Total Quality Management, 20(2), 139-152.

Stafford, T. (1994). Consumption values and the choice of marketing electives: Treating students like customers. Journal of Marketing Education, 16(2), 26-33.

Stone, M. (1974). Cross-validatory choice and assessment of statistical predictions. Journal of the Royal Statistical Society: Series B (Methodological), 36(2), 111-133. 
Sultan, P., \& Wong, H. (2010a). Performance-based service quality model: An empirical study on Japanese universities. Quality Assurance in Education, 18(2), 126-43.

Sweeny, J.C., \& Soutar, G.N. (2001). Consumer perceived value: The development of a multiple item scale. Journal of Retailing, 77(2), 203-220.

Sweeny, J.C., Soutar, G.N., \& Jhonson, L.W. (1997). Retail service quality and perceived value: A comparison of two models. Journal of Retailing and Consumer Services, 4(1), 39-48.

Vicere, A. (1998). Changes in practices, changes in perspectives: The 1997 international study of executive development trends. Journal of Management Development, 17(7), 526-543.

Webb, D., \& Jagun, A. (1997). Customer care, customer satisfaction, value, loyalty and complaining behavior: Validation in a UK university setting. Journal of Consumer Satisfaction, Dissatisfaction and Complainning Behavior, 10, 139-151.

Yeh, C-H., Wang, Y-S., \& Yieh, K. (2016). Predicting smartphone brand loyalty: Consumer value and consumer-brand identification perspectives. International Journal of Information Management, $36(3), 245-257$.

Yeo, R., \& Li, J. (2014). Beyond SERVQUAL: The competitive forces of higher education in Singapore. Total Quality Management \& Business Excellence, 25(1-2), 95-123.

Yildiz, S.M. (2014). Service quality evaluation in the school of physical education and sports: An empirical investigation of students' perceptions. Total Quality Management \& Business Excellence, 15(1-2), 80-94.

Zeithaml, V.A. (1988). Consumer Perception of Price, Quality, and Value: A Means-End Model and Synthesis of Evidence. Journal of Marketing, 52(3), 2-22. 